\title{
CARG Geological Database: new layers, new data
}

\author{
Loredana Battaglini $^{\text {a, * }}$, Roberta Carta ${ }^{\mathrm{b}}$ \\ ${ }^{a}$ Italian Institute for Environmental Protection and Research, ISPRA loredana.battaglini@isprambiente.it \\ ${ }^{b}$ Italian Institute for Environmental Protection and Research, ISPRA roberta.carta@isprambiente.it \\ * Loredana Battaglini
}

Keywords: CARG Project, Geodatabase, GIS, Guidelines

\begin{abstract}
:
The CARG Project, aimed at the realization of the New Geological Map of Italy at the scale 1:50,000 and at the informatisation of the related geological data, according to the specifications of the guidelines published in the QuaderniSGI, includes 633 geological and geotematic sheets covering the entire national territory.

In this context, following the refinancing of the CARG Project under Law 160/2019, the activity of implementing, revising and updating the structure and contents of the CARG Geological Database (CARG BD) has been planned.
\end{abstract}

The wide range of geological information acquired at a scale of 1:25,000 and derived from surface and subsurface surveys of emerged and submerged areas in the Italian territory, are stored within a complex geodatabase, structured in a series of information layers (15 layers), relationship and topological rules. The structure of the database includes spatial data, represented by the geometric primitives: lines, points and polygons, and by alphanumeric tabular data (14 related tables). These data are ruled by both logical and spatial relationships and constraints, established by specific guidelines, where dedicated dictionaries and domains for encoding fields are also described. These guidelines and standards are periodically updated and supplemented, to meet scientific needs and technological advances.

The logical model has an expandable structure that allows for improvements and additions but above all can be 'transferred and adapted' to a subsequent technologically up-to-date physical structure while maintaining the integrity of the data it contains.

Thanks to the new Project funding, a series of procedures have been started to revise, update and integrate both the hardware and software architecture and the scientific content of the CARG BD. The upgrading work mainly consists of the development of new technologies, the codification in lithological terms of the formations surveyed in the sheets, the implementation of information regarding the subsurface and the connection with various specialized databases of ISPRA, dedicated to mineral resources, geosites and sinkholes.

The CARG BD currently manages a large amount of geological data that are homogeneous in terms of structure, format, content details and quality; the coverage covers about $45 \%$ of the Italian territory and will be continuously expanded thanks to the resumption of surveys of new geological sheets.

A reliable database is an indispensable tool for basic geological knowledge, as it allows an immediate and comprehensive view of the existing data in a specific area, enabling further in-depth studies to be planned where necessary or information gaps to be filled and is a key element for planning and interventions on the territory.

Combining different types of data, according to a scientific analysis, is also possible to derive and elaborate further thematic maps and support new research on tectonics, resources and the environment as well as land planning and management.

\section{References}

- Servizio Geologico d'Italia (1992), “Carta Geologica d'Italia - 1:50.000. Guida al rilevamento.” Quaderni del Servizio Geologico Nazionale, serie III, vol. 1.

- Servizio Geologico d'Italia (1997), “Carta Geologica d'Italia - 1:50.000. BANCA DATI GEOLOGICI - Linee guida per l'informatizzazione e per l'allestimento per la stampa dalla banca” Quaderni del Servizio Geologico Nazionale, serie III, vol. 6

- Servizio Geologico d'Italia (2009), "Carta Geologica d'Italia - 1:50.000. Aggiornamento e integrazioni delle linee guida della Carta geologica d'Italia alla scala 1:50.000.” Quaderni del Servizio Geologico Nazionale, serie III, vol. 12 